\title{
Hak Warga Negara Dalam Pemenuhan Lingkungan Tempat Tinggal yang Layak Ditinjau dari Perspektif Hukum Hak Asasi Manusia
}

\author{
Atin Meriati Isnaini ${ }^{1}$ \\ Fakultas Hukum Universitas Islam Al- Azhar, \\ Jln. Majapahit No. 62 Mataram 83125, \\ Telp. (0370), 633035, Fax. 626954 \\ Email:atinmeriati@mail.com \\ Lalu Adnan Ibrahim ${ }^{2}$ \\ Fakultas Hukum Universitas Mataram, \\ Jln. Majapahit No. 62 Mataram 83125, \\ Telp. (0370), 633035, Fax. 626954 \\ Email:laluadnan@mail.com
}

\section{ABSTRAK}

Pembangunan nasional di Indonesia bertujuan untuk menciptakan masyarakat yang adil dan makmur berdasarkan Pancasila dan Undang-Undang Dasar 1945. Masyarakat yang adil dan makmur tersebut diartikan tidak hanya cukup sandang, pangan, dan papan saja tetapi justru harus diartikan sebagai cara bersama untuk memutuskan masa depan yang dicita-citakan dan juga turut secara bersama mewujudkan masa depan tersebut. Semangat untuk mewujudkan masa depan tersebut merupakan amanah dari mukadimah Undang-Undang Dasar 1945 alinea ke-4 juncto Pasal 28 H ayat (1) dan Pasal 33 UUD 1945.

Pembangunan perumahan yang dilakukan oleh pemerintah maupun pengembang merupakan upaya untuk memenuhi kebutuhan dasar manusia. Pembangunan perumahan ditujukan agar seluruh rakyat Indonesia menempati rumah yang layak dalam lingkungan yang sehat, aman, serasi, dan teratur. Rumah yang layak adalah bangunan rumah yang sekurang-kurangnya memenuhi persyaratan keselamatan bangunan dan kecukupan minimum luas bangunan serta kesehatan penghuninya. Lingkungan yang sehat, aman, serasi, dan teratur adalah lingkungan yang memenuhi persyaratan

1 Dosen Fakultas Hukum Universitas Islam Al-Azhar.

2 Dosen Fakultas Hukum Universitas Mataram. 
penataan ruang, persyaratan penggunaan tanah, penguasaan hak atas tanah, dan kelayakan prasarana dan sarana lingkungannya.

Dalam penelitian ini dikemukakan rumusan masalahnya adalah; Bagaimanakah hak kepemilikan rumah sebagai tempat tinggal yang layak dalam perspektif hukum hak asasi manusia, dan Bagaimanakah tanggung jawab pemerintah dalam memberi jaminan perlindungan atas pemenuhan hak kepemilikan rumah sebagai tempat tinggal yang layak di Indonesia. Tinjuan Pustaka yang jabarkan adalah tentang konsep dasar dan perkembangan pemikiran tentang HAM, konsep hak atas perumahan serta, dan perumahan sebagai tempat tinggal yang layak. Kemudian jenis dan metode penelitian ini adalah yuridis normatif dengan metode analisis Analisis bahan hukum dalam penelitian ini dilakukan dengan normatif-kualitatif, yakni dengan melakukan penafsiran sebagai upaya untuk mengkonstruksikan pernyataan yang terdapat dalam dokumen dan perundang-undangan.

Kata Kunci : Perumahan dalam Perspektif HAM.

\section{A. PENDAHULUAN}

Undang-Undang Dasar Negara Republik Indonesia Tahun 1945, Pasal 28H ayat (1) menegaskan bahwa setiap orang berhak hidup sejahtera, lahir dan batin, bertempat tinggal, dan mendapatkan lingkungan hidup yang baik dan sehat. Tempat tinggal mempunyai peran strategis dalam pembentukan watak dan kepribadian bangsa serta sebagai salah satu upaya membangun manusia Indonesia seutuhnya, berjati diri, mandiri, dan produktif.

Meningkatnya kebutuhan akan perumahan dan permukiman sangat erat kaitannya dengan kependudukan, seperti jumlah penduduk, laju pertumbuhannya, dan perubahan rata-rata jumlah jiwa keluarga. Hal tersebut merupakan masalah yang dihadapi, terutama di kota-kota besar di Indonesia, seperti Jakarta, Bandung, Surabaya, Medan, dan Semarang. Menurut A.P Parlindungan, pembangunan rumah susun, terutama di wilayah perkotaan, merupakan suatu kemutlakan sebagai akibat terbatasnya tanah untuk perumahan tersebut dan permintaan akan papan semakin tinggi. ${ }^{1}$

Dari latar belakang di atas maka peneliti mencoba mengangkat masalah tanggung jawab negara dalam menjamin pemenuhan lingkungan tempat tinggal yang layak ini dengan judul; "Hak Warga Negara dalam Pemenuhan Lingkungan Tempat Tinggal yang Layak Ditinjau dari Perspektif Hukum Hak Asasi Manusia”.

\section{B. PEMBAHASAN}

\section{Hak atas Kepemilikan Rumah sebagai Tempat Tinggal yang Layak dalam Perspektif Hukum HAM.}

Perumahan yang layak sungguh penting bagi semua orang, Pusat Pemukiman Manusia Perserikatan BangsaBangsa memperkirakan bahwa lebih dari 1 miliar manusia di seluruh dunia tinggal dalam rumah yang tidak layak, sedang 100 juta manusia diantaranya hidup dalam kondisi yang dikategorikan tidak mempunyai rumah. Akses untuk mendapatkan air minum dan fasilitas sanitasi yang layak merupakan kebutuhan dasar tambahan yang berhubungan langsung dangan perumahan. Perumahan yang layak, secara universal hukum hak asasi manusia, dipandang sebagai salah satu

1 A.P.Parlindungan, 2001, Komentar Atas Undang-Undang Perumahan dan Pemukiman dan Undang-Undang Rumah Susun, Bandung, Mandar Maju, hal. 91. 
kebutuhan paling dasar bagi manusia. ${ }^{2}$

Berdasarkan gambaran yang disampaikan WHO bahwa; 1,2 miliar orang di negara berkembang tidak memiliki akses untuk mendapatkan air minum, dan 1,8 miliar orang hidup tanpa memiliki fasilitas sanitasi yang layak (Laporan Perkiraan Dasawarsa 1990 WHO). Gambaran ini memberikan ilustrasi tentang besarnya skala perjuangan global untuk memenuhi hak atas perumahan yang layak. Tahun Internasional bagi Pemukiman untuk Orang yang Tidak Memiliki Perumahan pada 1987 membuat semakin meningkatnya kesadaran masyarakat terhadap masalah perumahan dan masalah-masalah terkait yang masih tersebar di seluruh dunia. Setelah Tahun Internasional tersebut, Strategi Global tentang Pemukiman hingga Tahun 2000 terus mengedepankan masalah perumahan, dan berhasil menaikkan posisi masalah hak atas perumahan dalam agenda perhatian PBB tentang hak asasi manusia dibanding masa sebelumnya. ${ }^{3}$

Hak atas perumahan yang layak merupakan pilar dari Strategi Pemukiman Global:

Hak atas perumahan yang layak mendapat pengakuan secara universal oleh masyarakat dari berbagai bangsa.... Setiap bangsa, tanpa terkecuali, memiliki sejumlah kewajiban dalam masalah perumahan, misalnya nampak dengan dibentuknya kementerian perumahan atau lembaga-lembaga perumahan, pengalokasian dana untuk sektor perumahan, dan dengan kebijakan, program serta proyek.... Setiap warga negara suatu negara, semiskin apa pun dirinya, mempunyai hak untuk mengharap bahwa pemerintah akan memperhatikan kebutuhan mereka atas perumahan, dan

\footnotetext{
2 Allan Mc Chesney, Memajukan dan Membela HakHak Ekonomi, Sosial, dan Budaya, Insist Press, Yogyakarta, 2003.

${ }^{3}$ Ibid.
}

untuk menerima kewajiban dasar untuk melindungi dan memperbaiki perumahan serta lingkungannya, dan bukan malahan merusak atau menghancurkannya. ${ }^{4}$

Pengertian dari perumahan yang layak dijabarkan di dalam Strategi Global sebagai: lingkungan pribadi yang layak, ruang yang layak, keamanan yang layak, penerangan dan ventilasi yang layak, prasarana dasar yang layak dan lokasi yang layak dengan memperhatikan pekerjaan serta fasilitas-fasilitas dasar, dan semua dengan harga yang layak. Lalu bagaimana peraturan internasional tentang hak asasi manusia dapat menterjemahkan masalah perumahan yang layak ini dalam pelaksanaan suatu rumusan hukum?

Dengan ditetapkannya DUHAM pada 1948, hak atas perumahan yang layak menjadi bagian dari hukum hak asasi manusia internasional yang diterima dan dapat diterapkan secara universal. Sejak saat itu hak ini telah berulangkali ditegaskan melalui sejumlah besar instrumen hak asasi manusia tambahan, yang masing-masing mempunyai relevansi pada kelompok-kelompok yang berbeda di dalam masyarakat. Tidak kurang dari 12 naskah telah ditetapkan dan diproklamirkan oleh PBB yang secara tegas memberi pengakuan atas hak atas perumahan yang layak. $^{5}$

Banyak dari instrumen yang mengakui hak atas perumahan yang layak mengedepankan bahwa setiap orang berhak mendapatkan hak ini. Hal ini penting, karena walaupun naskah-naskah lain menyebutkan bahwa hak atas perumahan yang layak merupakan hak yang melekat dalam kaitannya dengan kelompokkelompok tertentu (sehingga memberikan perlindungan hukum tambahan bagi

\footnotetext{
${ }^{4}$ Asbjorn Eide, Catarina Krause, and Allan Rosas (ed.), 2001, Economic, Social and Cultural Rights, Martinus Nijhoff Publishers, hal. 84. 5 Ibid.
} 
kelompok-kelompok tersebut), pada akhirnya perumahan yang layak merupakan hak setiap anak-anak, perempuan dan pria dimana pun mereka berada.

Pasal 25 ayat 1 DUHAM memproklamirkan bahwa:

Setiap orang mempunyai hak untuk mendapatkan standar hidup yang layak atas kesehatan dan kehidupan serta keluarganya, termasuk makanan, pakaian, perumahan dan perawatan kesehatan serta pelayanan sosial yang dibutuhkan, dan hak untuk diperlakukan sama pada saat menganggur, sakit, cacat, menjanda, lanjut usia, dan ketidak mampuan lain untuk menjalankan kehidupan yang bukan timbul atas kehendaknya.

Kovenan Internasional tentang Hak Ekonomi, Sosial dan Budaya telah diratifikasi atau disetujui oleh 108 Negara. Naskah Kovenan ini memuat landasan yang mungkin paling signifikan bagi hak atas perumahan di antara semua prinsip hukum yang ada, yang memuat aturan tentang hak asasi manusia internasional.

Pasal 11 ayat 1 dari Kovenan Ekosob ini menyatakan bahwa:

Negara-negara Pihak pada Kovenan ini mengakui hak setiap orang atas kehidupan yang layak untuk dirinya sendiri dan keluarganya, termasuk kelayakan pangan, sandang dan papan, dan perbaikan kondisi hidup yang terus menerus. Negara-negara Pihak akan mengambil langkah-langkah yang tepat untuk menjamin perwujudan hak tersebut, dengan mengakui arti penting yang esensial dari kerja sama internasional yang didasarkan pada kesepakatan sukarela. ${ }^{6}$

Di samping kedua hal ini, Deklarasi PBB tentang Kemajuan dan Pembangunan Sosial (1969) serta Deklarasi Vancouver tentang Pemukiman Manusia PBB (1976) mengakui hak setiap orang atas perumahan yang layak. Konvensi Internasional mengenai Penghapusan Segala Bentuk Diskriminasi Ras saat ini merupakan naskah yang paling banyak diratifikasi di antara seluruh naskah hak asasi manusia PBB. $^{7}$

Pasal 5 (e) dari Konvensi ini memasukan kewajiban negara pihak untuk: melarang dan menghapuskan diskriminasi rasial dalam segala bentuknya dan untuk memberi jaminan atas hak setiap orang, tanpa pembedaan seperti ras, warna kulit atau kebangsaan atau suku asal, atas persamaan di muka hukum, khususnya dalam penikmatan atas hak ekonomi, sosial dan budaya terutama.....hak atas perumahan.

Perlakuan yang sama juga merupakan landasan yang berlaku bagi setiap perempuan dalam mendapatkan hak atas perumahan, di antara hak-hak lainnya. Berdasarkan Pasal 14 Konvensi mengenai Penghapusan Segala Bentuk Diskriminasi Terhadap Perempuan, secara khusus Negara-negara Pihak diminta untuk menghapuskan diskriminasi terhadap perempuan di daerah pedesaan, dan untuk menjamin hak mereka dalam menikmati kondisi kehidupan yang layak bagi kaumnya, khususnya sehubungan dengan masalah perumahan, sanitasi, listrik dan distribusi air. ${ }^{8}$

Baik Deklarasi PBB tentang Hak Anak (1959) maupun Konvensi tentang Hak Anak (1989) membahas masalah khusus tentang hak atas perumahan bagi anak-anak. Pasal 27 Konvensi menghendaki Negara-negara Pihak agar melakukan upaya-upaya yang tepat untuk membantu para orang tua dan penanggungjawab anak-anak lainnya untuk menerapkan hak atas standar hidup yang layak, dan: apabila dibutuhkan (untuk) memberikan bahan-bahan bantuan dan program-program pendukung, khususnya tentang gizi, pakaian dan perumahan. ${ }^{9}$

\footnotetext{
${ }^{6}$ Manfred Nowak, 2003, Introduction to the International Human Rights Regime, Martinus Nijhoff Publishers, hal. 201.
}

${ }^{7}$ Asbjorn EideOp, Cit, 2001.

${ }^{8}$ Ibid.

${ }^{9}$ Ibid. 
Hak pekerja migran untuk mendapat perlakuan yang sama dalam masalah perumahan dijamin dalam Pasal 43 Konvensi Internasional tentang Perlindungan terhadap Hak Pekerja Migran dan Anggota Keluarganya (1990). Pasal ini menyebutkan bahwa:

Pekerja Migran harus dapat menikmati perlakuan yang sama dengan warga negara dari Negara tempat ia bekerja, sehubungan dengan......(d) akses atas perumahan, termasuk lingkungan sosial perumahan, dan perlindungan terhadap eksploitasi dalam hal sewa rumah.

Naskah hukum internasional yang paling banyak membahas masalah perumahan adalah Rekomendasi Organisasi Buruh Internasional No. 115 tentang Perumahan bagi Pekerja, tahun 1961. Rekomendasi ini memuat sejumlah pasal yang mengakui pentingnya masalah perumahan, dan memperkokoh landasan hukum bagi hak atas perumahan. Setelah mencatat dalam pembukaannya bahwa Konstitusi ILO mengakui sejumlah besar kewajiban organisasi melanjutkan programprogram untuk memenuhi ketentuan tentang perumahan yang layak. Rekomendasi No. 115 menyatakan bahwa:

Harus ada kebijakan nasional yang obyektif tentang perumahan untuk.....(memastikan) bahwa akomodasi perumahan yang layak dan baik serta lingkungan hidup yang pantas dapat diperoleh setiap pekerja dan keluarganya. Skala prioritas harus diberikan kepada mereka yang paling membutuhkan.

Secara keseluruhan, 37 konvensi dan rekomendasi-rekomendasi menyebutkan dalam satu atau lainnya masalah tentang perumahan.

Berdasarkan Konvensi tahun 1951 mengenai Kedudukan Pengungsi, Negara- negara yang melakukan perjanjian diharuskan untuk memperlakukan para pengungsi sebaik mungkin, dan tidak lebih buruk dari pada perlakuan yang diberikan pada orang asing umumnya dalam situasi yang sama, sehubungan dengan masalah perumahan.

Di samping itu untuk menjadi bagian dari berbagai perjanjian dan deklarasi yang baru disebutkan, hak atas perumahan yang layak juga telah dikemukakan dalam sejumlah resolusi yang ditetapkan oleh berbagai jenis badan pembuat keputusan PBB. Walaupun resolusi-resolusi tersebut tidak mengikat secara hukum, resolusi tersebut menjalankan fungsi penting dalam menyampaikan standar yang diterima secara internasional. Metode pengakuan ini mengungkapkan perhatian dan dukungan global yang terus menerus diberikan terhadap hak atas perumahan oleh masyarakat internasional, setidaknya secara prinsip. ${ }^{10}$ Sebagian besar resolusi tentang hak-hak atas perumahan ditujukan kepada Pemerintah-pemerintah, dengan maksud untuk mendorong mereka berusaha lebih banyak lagi bagi pelaksanaan hak-hak tersebut.

Sifat tidak terpisahkan dan saling tergantung dari seluruh hak asasi manusia dengan jelas tercermin dalam hak atas perumahan. Sebagaimana diakui oleh sejumlah badan hak asasi manusia PBB, penikmatan sepenuhnya hak-hak seperti hak atas martabat manusia, prinsip non diskriminasi, hak mendapatkan standar hidup yang layak, hak untuk bebas memilih tempat tinggalnya sendiri, hak untuk berkumpul dan mengeluarkan pendapat (seperti bagi penyewa dan kelompok komunitas lainnya), hak atas keamanan seseorang (dalam hal pengusiran secara paksa atau sewenang-wenang atau pelecehan dalam bentuk lainnya) serta hak

${ }^{10}$ Manfred Nowak, Op.Cit., hal. 92. 
untuk tidak menjadi korban dari campur tangan semena-mena terhadap masalah pribadi, keluarga dan rumah seseorang atau kenalannya merupakan hal yang sangat diperlukan supaya hak atas perumahan dapat diwujudkan, dilaksanakan dan dipertahankan oleh semua kelompok dalam masyarakat.

Pengakuan hukum secara luas terhadap hak atas perumahan yang layak merupakan kebutuhan yang bersifat mutlak. Meskipun begitu, dari sisi pelaksanaannya, perlu dinyatakan langkah-langkah khusus yang harus dilakukan Pemerintah agar hakhak yang diatur hukum ini dapat direalisasikan bagi setiap orang. Kadang kala terjadi salah penafsiran bahwa hak seperti hak atas perumahan hanya sekedar mewajibkan negara untuk menyediakan dana masyarakat yang memadai untuk memenuhi kewajiban ini, dan bahwa pengalokasian lebih lanjut atas sumber moneter saja sudah cukup. Namun demikian, hak atas perumahan dan semua hak ekonomi, sosial dan budaya ternyata menuntut sejumlah kewajiban yang lebih banyak dan kompleks dari Negara-negara.

Komite untuk Hak Ekonomi, Sosial dan Budaya telah membantu untuk mengklarifikasi berbagai kewajiban pemerintah yang timbul akibat pengakuan terhadap hak atas perumahan yang layak. Hal ini telah dilakukan melalui berbagai inisiatif, diantaranya: ${ }^{11}$

(1) menyelenggarakan "diskusi umum" tentang hak ini;

(2) secara komprehensif memperbaiki pedoman untuk laporan negara berdasarkan Pasal 16 dan 17 Kovenan Internasional tentang Hak Ekonomi, Sosial dan Budaya;

(3) menetapkan Keterangan Umum No. 4 tentang Hak atas Perumahan yang Layak;

(4) menyertakan catatan ke dalam kesimpulan akhir beberapa laporan Negara Pihak, yang menunjukkan bahwa negara yang dimaksud telah menyalahi hak atas perumahan yang layak dengan melakukan pengusiran secara paksa.

Langkah-langkah ini, dan tentu saja aturan Kovenan dan sumber hukum lain tentang hak atas perumahan tersebut di atas, telah meningkatkan berbagai kewajiban pemerintah terhadap pelaksanaan hak-hak ini. Kewajiban hukum Pemerintah berkenaan dengan hak atas perumahan terdiri dari (i) tugas-tugas yang tercantum dalam pasal 2 ayat 1 Kovenan; dan (ii) kewajiban yang lebih spesifik untuk mengakui, menghormati, melindungi dan memenuhi hak ini dan hak-hak lainnya. ${ }^{12}$

Pasal 2 ayat 1 Kovenan merupakan masalah pokok untuk menentukan apa yang harus dilakukan Pemerintah dan apa yang harus dicegah untuk dilakukan dalam proses menuju penikmatan oleh masyarakat secara luas atas hak-hak yang tercantum dalam Kovenan. Pasal ini berbunyi seperti berikut:

Setiap Negara Pihak pada Kovenan ini berjanji untuk mengambil langkahlangkah, baik secara sendiri-sendiri maupun melalui bantuan dan kerja sama internasional, terutama dalam bidang ekonomi dan tehnis, dengan menggunakan secara maksimum sumberdaya yang dimilikinya, untuk secara bertahap mencapai pelaksanaan sepenuhnya hakhak yang diakui dalam Kovenan saat ini melalui semua upaya yang tepat, khususnya termasuk penetapan peraturan-peratuaran legislatif.

Tiga bagian kalimat dalam pasal di atas sangat penting untuk memahami kewajiban Pemerintah dalam melaksanakan sepenuhnya hak-hak yang diakui dalam Kovenan, termasuk hak atas perumahan yang layak: ${ }^{13}$

11 Tim Komnas HAM, 2009, Komentar Umum Hak Sipol Dan Hak Ekosob, Komnas HAM, Jakarta, hal. 45.

13 Manfred Nowak, Op.Cit., hal. 245. 
1) "berjanji untuk melakukan langkahlangkah ..... melalui segala upaya yang tepat";

2) "dengan memanfaatkan secara maksimum sumber daya yang tersedia"; dan

3) "untuk secara bertahap mencapai."

1) "berjanji untuk melakukan langkahlangkah......melalui segala upaya yang tepat"

Kalimat "melalui upaya yang tepat" telah diterjemahkan secara luas. Di samping peraturan perundangan, langkah-langkah administratif, hukum, ekonomi, sosial dan pendidikan juga harus dilakukan. Secara umum, Pemerintah juga harus mengambil langkah yang hati-hati, konkrit dan terarah sebaik mungkin, dalam melaksanakan kewajiban yang diakui Kovenan. Dibutuhkan langkah cepat dan berkesinambungan untuk mempelajari keadaan yang terjadi berkenaan dengan hak-hak yang tercantum dalam Kovenan.

2) "dengan memanfaatkan secara maksimum sumber daya yang tersedia" Prinsip ini menuntut adanya akses yang cukup serta penggunaan yang efektif dari sumberdaya yang tersedia. Walaupun ketidak-tersediaan sumber daya sering digunakan sebagai alasan tidak dapat dipenuhinya suatu hak tertentu, Komite Hak Ekonomi, Sosial dan Budaya telah menegaskan bahwa meskipun di saat terjadi penurunan kondisi ekonomi yang hebat dan Negara sedang melakukan upayaupaya perbaikan struktural, anggota kelompok masyarakat lemah dapat dan bahkan harus dilindungi melalui penetapan program-program murah. Apabila suatu Negara menyatakan bahwa ia tidak dapat memenuhi kewajiban terkecil sekalipun karena tidak adanya sumber daya, maka setidak-tidaknya harus dibuktikan bahwa segala usaha telah dilakukan untuk memanfaatkan setiap sumberdaya yang terbuang dalam usaha memenuhi kewajiban minimumnya. Tidak tersedianya sumber daya tidak selalu dapat digunakan untuk menilai kesalahan negara dalam memenuhi kewajibannya untuk memantau tidak terpenuhinya hak-hak yang tercantum dalam Kovenan.

3) "untuk secara bertahap mencapai" Kewajiban "untuk secara bertahap mencapai" ini harus dibaca dalam pengertian Pasal 11 Kovenan, khususnya pada masalah tentang hak untuk "perbaikan kondisi kehidupan yang berkesinambungan." Setiap upaya untuk sengaja mengendurkan masalah (retrogesif) tersebut, harus dipertimbangkan dengan sangat hatihati serta perlu diberikan alasan yang dapat diterima dengan mengacu pada keseluruhan hak yang dicantumkan dalam Kovenan, dan dalam konteks pemanfaatan sepenuhnya sumbersumber yang tersedia.

Di atas tuntutan pokok ini terdapat empat kewajiban tambahan bagi negara sehubungan dengan hak atas perumahan yang layak, sebagai berikut:

1. Negara mengakui hak atas perumahan;

2. Kewajiban negara menghormati hak atas perumahan;

3. Kewajiban negara melindungi hak atas perumahan;

4. Kewajiban negara mmenuhi hak atas perumahan.

2. Tanggung Jawab Pemerintah dalam Memberi Jaminan Perlindungan atas Pemenuhan Kepemilikan Rumah sebagai Tempat Tinggal yang Layak di Indonesia. 
Hak asasi manusia adalah hak yang dilindungi oleh hukum nasional dan hukum internasional. Demikian pula halnya Indonesia sebagai negara yang mengakui HAM sebagai anugrah Tuhan yang perlu dilindungi dan ditegakkan sesuai dengan ketentuan peraturan perundang-undangan yang berlaku. Dasar perlindungan hukum atas HAM di Indonesia terdapat dalam Pembukaan Undang-Undang Dasar 1945 alinea IV, Bab XA Undang-Undang Dasar 1945 (Pasal 28A sampai dengan Pasal 28J), Undang-Undang Nomor 39 Tahun 1999 tentang Hak Asasi Manusia, serta UndangUndang Nomor 26 Tahun 2000 tentang Pengadilan HAM. ${ }^{14}$

Pasal 28 I ayat (4) UUD 1945 secara tegas menyatakan bahwa perlindungan, pemajuan, penegakan, dan pemenuhan hak asasi manusia adalah tanggung jawab negara, terutama pemerintah. Demikian pula dijelaskan dalam Undang-Undang Nomor 39 Tahun 1999 tentang HAM Pasal 71 yang menyatakan:

"Pemerintah wajib dan bertanggung jawab menghormati, melindungi, menegakkan, dan memajukan hak asasi manusia yang diatur dalam undang-undang ini, peraturan perundang-undangan lain, dan hukum internasional tentang hak asasi manusia yang diterima oleh negara Republik Indonesia”.

Berdasarkan perintah undang-undang tersebut telah jelas bahwa pemerintah mempunyai tanggung jawab untuk menghormati, melindungi, menegakkan, dan memajukan hak asasi manusia.

Dasar pemerintah menetapkan peraturan tentang perumahan sebagai tempat tinggal yang layak sebagaimana ditentukan konstitusi negara yakni dalam Undang-Undang Dasar Negara Republik Indonesia Tahun 1945, Pasal 28H ayat (1) menyebutkan bahwa;

"setiap orang berhak hidup sejahtera lahir dan batin, bertempat tinggal, dan mendapatkan lingkungan hidup yang baik dan sehat. Tempat tinggal mempunyai peran yang sangat strategis dalam pembentukan watak serta kepribadian bangsa sebagai salah satu upaya membangun manusia Indonesia seutuhnya, berjati diri, mandiri, dan produktif sehingga terpenuhinya kebutuhan tempat tinggal merupakan kebutuhan dasar bagi setiap manusia, yang akan terus ada dan berkembang sesuai dengan tahapan atau siklus kehidupan manusia".

Negara bertanggung jawab melindungi segenap bangsa Indonesia melalui penyelenggaraan perumahan dan kawasan permukiman agar masyarakat mampu bertempat tinggal serta menghuni rumah yang layak dan terjangkau di dalam lingkungan yang sehat, aman, harmonis, dan berkelanjutan di seluruh wilayah Indonesia. Sebagai salah satu kebutuhan dasar manusia, idealnya rumah harus dimiliki oleh setiap keluarga, terutama bagi masyarakat yang berpenghasilan rendah dan bagi masyarakat yang tinggal di daerah padat penduduk di perkotaan.

Pembangunan perumahan dan kawasan permukiman yang bertumpu pada masyarakat memberikan hak dan kesempatan seluas-luasnya bagi masyarakat untuk ikut berperan. Sejalan dengan peran masyarakat di dalam pembangunan perumahan dan kawasan permukiman, Pemerintah dan pemerintah daerah mempunyai tanggung jawab untuk menjadi fasilitator, memberikan bantuan dan kemudahan kepada masyarakat, serta melakukan penelitian dan pengembangan yang meliputi berbagai aspek yang terkait, antara lain, tata ruang, pertanahan, prasarana lingkungan, industri bahan dan komponen, jasa konstruksi dan rancang bangun, pembiayaan, kelembagaan, sumber daya manusia, kearifan lokal, serta peraturan perundang-undangan yang

14 Titon Slamet Kurnia, Reparasi terhadap Korban Pelanggaran HAM di Indonesia, Citra Aditya Bakti, Bandung, 2005, hlm. 23. 
mendukung.

Lebih lanjut ditegaskan sebagai dasar pemerintah menetapkan peraturan tentang perumahan sebagai tempat tinggal yang layak sebagaimana ditentukan dalam Pertimbangan Undang-Undang Nomor 1 Tahun 2011 tentang Perumahan dan Kawasan Permukiman adalah sebagai berikut:

a. bahwa setiap orang berhak hidup sejahtera lahir dan batin, bertempat tinggal, dan mendapatkan lingkungan hidup yang baik dan sehat, yang merupakan kebutuhan dasar manusia, dan yang mempunyai peran yang sangat strategis dalam pembentukan watak serta kepribadian bangsa sebagai salah satu upaya membangun manusia Indonesia seutuhnya, berjati diri, mandiri, dan produktif;

b. bahwa negara bertanggung jawab melindungi segenap bangsa Indonesia melalui penyelenggaraan perumahan dan kawasan permukiman agar masyarakat mampu bertempat tinggal serta menghuni rumah yang layak dan terjangkau di

c. dalam perumahan yang sehat, aman, harmonis, dan berkelanjutan di seluruh wilayah Indonesia;

d. bahwa pemerintah perlu lebih berperan dalam menyediakan dan memberikan kemudahan dan bantuan perumahan dan kawasan permukiman bagi masyarakat melalui penyelenggaraan perumahan dan kawasan permukiman yang berbasis kawasan serta keswadayaan masyarakat sehingga merupakan satu kesatuan fungsional dalam wujud tata ruang fisik, kehidupan ekonomi, dan sosial budaya yang mampu menjamin kelestarian lingkungan hidup sejalan dengan semangat demokrasi, otonomi daerah, dan keterbukaan dalam tatanan kehidupan bermasyarakat, berbangsa, dan bernegara;

e. bahwa pertumbuhan dan pembangunan wilayah yang kurang memperhatikan keseimbangan bagi kepentingan masyarakat berpenghasilan rendah mengakibatkan kesulitan masyarakat untuk memperoleh rumah yang layak dan terjangkau;

f. bahwa Undang-Undang Nomor 4 Tahun 1992 tentang Perumahan dan Permukiman sudah tidak sesuai dengan perkembangan dan kebutuhan perumahan dan permukiman yang layak dan terjangkau dalam lingkungan yang sehat, aman, serasi, dan teratur sehingga perlu diganti;

Menurut Penjelasan UU No. 1 Tahun 2011 menentukan bahwa kebijakan umum pembangunan perumahan diarahkan untuk:

a. memenuhi kebutuhan perumahan yang layak dan terjangkau dalam lingkungan yang sehat dan aman yang didukung prasarana, sarana, dan utilitas umum secara berkelanjutan serta yang mampu mencerminkan kehidupan masyarakat yang berkepribadian Indonesia;

b. ketersediaan dana murah jangka panjang yang berkelanjutan untuk pemenuhan kebutuhan rumah, perumahan, permukiman, serta lingkungan hunian perkotaan dan perdesaan;

c. mewujudkan perumahan yang serasi dan seimbang sesuai dengan tata ruang serta tata guna tanah yang berdaya guna dan berhasil guna; 
d. memberikan hak pakai dengan tidak mengorbankan kedaulatan negara; dan

e. mendorong iklim investasi asing. Salah satu rintangan dalam mewujudkan hak atas perumahan adalah tidak adanya pengakuan universal terhadap definisi dari sejumlah hal yang mencerminkan norma ini. Rintangan tersebut mungkin lebih merupakan hasil penafsiran daripada analisis hukum yang sebenarnya. Baru-baru ini, telah diambil sejumlah langkah-langkah untuk menjernihkan pendekatan hukum terhadap masalah ini. Hal terpenting adalah Keterangan Umum No. 4 dari Komite Hak Ekonomi, Sosial dan Budaya tentang Hak atas Perumahan yang Layak, yang merumuskan hak ini sebagai kumpulan dari berbagai permasalahan yang spesifik. Secara keseluruhan, hak-hak ini membentuk suatu jaminan pokok, yang berdasarkan hukum internasional secara yuridis melekat pada setiap orang, yang meliputi;

1. Jaminan Hukum atas Hak Huni;

2. Ketersediaan Pelayanan, Material dan Infrastruktur ;

3. Perumahan yang Terjangkau Harganya ;

4. Perumahan yang Layak Huni ;

5. Perumahan yang Dapat Diakses;

6. Lokasi, dan

7. Perumahan yang Layak Secara Budaya

Persoalan apakah prinsip hukum pembenaran (justiciability) atau ketentuan tentang upaya pemulihan hukum domestik dapat diterapkan pada hak ekonomi, sosial dan budaya - khususnya hak atas perumahan yang layak - telah dengan tegas dijawab oleh Komite Hak Ekonomi, Sosial dan Budaya. Menurut Komite ini, bidangbidang di mana ketentuan tersebut dapat diterapkan mencakup:

a. Permohonan hukum untuk mencegah pengusiran terencana atau pembongkaran melalui putusan pengadilan berupa perintah untuk menghentikannya; b. Prosedur hukum untuk permintaan ganti rugi akibat pengusiran yang melawan hukum;

c. Pengaduan terhadap tindakan melawan hukum yang dilakukan atau didukung oleh tuan tanah (baik pemerintah atau swasta) sehubungan dengan tingkat harga sewa, pemeliharaan pemukiman, dan bentuk-bentuk diskriminasi ras atau diskriminasi lainnya.

d. Tuduhan atas setiap bentuk diskriminasi dalam pengalokasian dan penyediaan akses atas perumahan;

e. Pengaduan terhadap tuan tanah sehubungan dengan kondisi perumahan yang tidak sehat atau tidak layak; dan

f. Gugatan class action dalam situasi yang membuat makin bertambahnya jumlah orang yang tidak memiliki perumahan. ${ }^{15}$

Sejalan dengan arah kebijakan umum tersebut, penyelenggaraan perumahan dan permukiman, baik di daerah perkotaan yang berpenduduk padat maupun di daerah pedesaan yang ketersediaan lahannya lebih luas perlu diwujudkan adanya ketertiban dan kepastian hukum dalam pengelolaannya. Pemerintah dan pemerintah daerah perlu memberikan kemudahan perolehan rumah bagi masyarakat berpenghasilan rendah melalui program perencanaan pembangunan perumahan secara bertahap dalam bentuk pemberian kemudahan pembiayaan dan/atau pembangunan prasarana, sarana, dan utilitas umum di lingkungan hunian.

Sebagaimana ditentukan oleh Pasal 3 UU No. 1 Tahun 2011, perumahan dan kawasan permukiman diselenggarakan untuk:

a) memberikan kepastian hukum dalam penyelenggaraan perumahan dan kawasan permukiman;

b) mendukung penataan dan pengembangan wilayah serta

15 Ibid., hal. 208. 
penyebaran penduduk yang proporsional melalui pertumbuhan lingkungan hunian dan kawasan permukiman sesuai dengan tata ruang untuk mewujudkan keseimbangan kepentingan, terutama bagi MBR (Masyarakat Berpenghasilan Rendah);

c) meningkatkan daya guna dan hasil guna sumber daya alam bagi pembangunan perumahan dengan tetap memperhatikan kelestarian fungsi lingkungan, baik di kawasan perkotaan maupun kawasan pedesaan;

d) memberdayakan para pemangku kepentingan bidang pembangunan perumahan dan kawasan permukiman;

e) menunjang pembangunan di bidang ekonomi, sosial, dan budaya; dan

f) menjamin terwujudnya rumah yang layak huni dan terjangkau dalam lingkungan yang sehat, aman, serasi, teratur, terencana, terpadu, dan berkelanjutan.

Penyelenggaraan perumahan dilakukan untuk memenuhi kebutuhan rumah sebagai salah satu kebutuhan dasar manusia bagi peningkatan dan pemerataan kesejahteraan rakyat, yang meliputi perencanaan perumahan, pembangunan perumahan, pemanfaatan perumahan dan pengendalian perumahan. Salah satu hal khusus yang diatur dalam undang-undang ini adalah keberpihakan negara terhadap masyarakat berpenghasilan rendah.

Ketentuan Pasal 5 UU No. 1 Tahun 2011 menentukan bahwa;

(1) Negara bertanggung jawab atas penyelenggaraan perumahan dan kawasan permukiman yang pembinaannya dilaksanakan oleh pemerintah;

(2) Pembinaan sebagaimana dimaksud pada ayat dilaksanakan oleh:

a. Menteri pada tingkat nasional;

b. gubernur pada tingkat provinsi; dan

c. bupati/walikota pada tingkat kabupaten/kota.

Undang-undang perumahan dan kawasan permukiman ini juga mencakup pemeliharaan dan perbaikan yang dimaksudkan untuk menjaga fungsi perumahan dan kawasan permukiman agar dapat berfungsi secara baik dan berkelanjutan untuk kepentingan peningkatan kualitas hidup orang perseorangan yang dilakukan terhadap rumah serta prasarana, sarana, dan utilitas umum di perumahan, permukiman, lingkungan hunian dan kawasan permukiman.

\section{PENUTUP}

Sesuai dengan pembahasan di atas, maka dapat ditarik kesimpulan sebagai berikut:

1. Dalam perspektif hukum hak asasi asasi manusia internasional telah menetapkan bahwa jaminan perlindungan dan pemenuhan hak warga negara atas kepemilikan perumahan sebagai tempat tinggal yang layak merupakan bagian dari bentuk jaminan perlindungan atas hak asasi manusia di bidang ekonomi, sosial dan budaya yang harus diberikan bagi setiap negara terhadap warga negaranya.

2. Tanggung jawab pemerintah Indonesia dalam memberi jaminan atas hak warga negara dalam pemenuhan perumahan sebagai tempat tinggal yang layak diatur dalam Undang-Undang Dasar Negara Republik Indonesia Tahun 1945 Pasal $28 \mathrm{H}$ ayat (1), dan Undang- 
Undang Nomor 1 Tahun 2011 tentang Perumahan dan Kawasan Permukiman. Hal ini dapat diwujudkan antara lain dengan: (1) Jaminan hukum atas hak huni; (2) Ketersediaan Pelayanan material dan infrastruktur; (3) Perumahan yang terjangkau harganya; (4) Perumahan yang layak huni; (5) Perumahan yang mudah diakses; (6) Lokasi; dan (7) Perumahan yang layak secara budaya.

\section{Saran}

Saran yang dapat dikemukakan dalam penelitian ini, antara lain:

1. Negara atau Pemerintah Indonesia harus memenuhi dan menyediakan perumahan sebagai tempat tinggal yang layak bagi setiap warga negara sebagai suatu bukti bahwa negara telah serius memberi perlindungan HAM, khususnya jaminan perlindungan HAM generasi ketiga, yakni hak ekonomi sosial dan budaya bagi warganya.

2. Negara atau Pemerintah harus benarbenar konsen dalam menerapkan Peraturan perundang-undangan yakni Undang-Undang Nomor 1 Tahun 2011 tentang perumahan dan kawasan pemukiman, agar jaminan perlindungan dan pemenuhan hak atas perumahan dapat segara dirasakan oleh masyarakat, khususnya hak bagi masyarakat yang tingkat penghasilannya rendah demi tercapainya kesejateraan dan keadilan.

\section{DAFTAR PUSTAKA}

A.P. Parlindungan, Komentar Atas Undang-Undang Perumahan dan Pemukiman dan UndangUndang Rumah Susun, Bandung, Mandar Maju, 2001.

Allan Mc Chesney, Memajukan dan Membela Hak-Hak Ekonomi,
Sosial, dan Budaya, Insist Press, Yogyakarta, 2003

Alston Philp dan Franz Magnes Suseno (Kata Pengantar), Hukum Hak Asasi Manusia, PUSHAM UII, Yogyakarta, 2008.

Asbjorn Eide, Catarina Krause, and Allan Rosas (ed.), 2001, Economic, Social and Cultural Rights, Martinus Nijhoff Publishers, hal. 84.

Budiharjo, Sejumlah Masalah Permukiman Kota, Alumni, Bandung, 1992.

Ferejohn, John, Jack N. Rakove, and Jonathan Riley (eds). 2001, Constitutional Culture and Democratic Rule. Cambridge University Press, Cambridge, 2001.

Franz Magnis Suseno, Etika Politik: Prinsip-prinsip Moral Dasar Kenegaraan Modern. Jakarta: PT Gramedia Pustaka Utama, 1999.

Jimly Asshiddiqie, Konstitusi dan Konstitusionalisme Indonesia, Konstitusi Press, Jakarta, 2006.

M. Rizal Arif, Analisis Kepemilikan Hak Atas Tanah Satuan Rumah Susun Dalam Kerangka Hukum Benda, Bandung, Nuansa Aulia, 2009.

Manfred Nowak, Introduction to the International Human Rights Regime, Martinus Nijhoff Publishers, 2003.

Peter R. Baehr, Hak-hak Asasi Manusia dalam Politik Luar Negeri, Yayasan Obor Indonesia, Jakarta, 1998.

Tim Komnas HAM, Komentar Umum Hak Sipol Dan Hak Ekosob, Komnas HAM, Jakarta, 2009.

Titon Slamet Kurnia, Reparasi terhadap Korban Pelanggaran HAM di Indonesia, Citra Aditya Bakti, Bandung, 2005

\section{Peraturan Perundang-Undangan}

Undang-Undang Dasar Negara Republik Indonesia Tahun 1945 
Deklarasi Universal Hak Asasi Manusia (DUHAM)

Undang-Undang Nomor 39 Tahun 1999 tentang Hak Asasi Manusia.

Undang-undang Nomor 11 Tahun 2005 tentang Pengesahan Konvensi Internasional Hak ekonomi sosial dan budaya.

Undang-Undang Nomor 1 Tahun 2011 Tentang Perumahan dan Permukiman. 